The Federal Reserve BanK of Kansas City Research Working Papers

\title{
Competition and Bank Fragility
}

W. Blake Marsh and Rajdeep Sengupta

June 2017

RWP 17-06

https://dx.doi.org/10.18651/RWP2017-06 


\title{
Competition and Bank Fragility*
}

\author{
W. Blake Marsh ${ }^{\dagger} \quad$ Rajdeep Sengupta ${ }^{\dagger}$
}

First Draft: June 9, 2017

\begin{abstract}
We present empirical evidence documenting how increased competition can affect the fragility of banks using U.S. banking data from 1990 to 2005. In particular, we find that local banks belonging to community (CBOs) and regional banking organizations (RBOs) increased their share of CRE loans as competition from large banking organizations (LBOs) increased. The paper traces the build-up in CRE concentrations in such local banks before the financial crisis to the expansions of LBO activity into local banking markets. After instrumenting for LBO entry into new markets, we find a steady and continuous increase in CRE loan shares at local banks. CRE concentrations were a principal cause of post-crisis bank failures, and this paper presents evidence showing how competition increases not just individual bank fragility, but the stability of the banking sector as a whole.
\end{abstract}

JEL Classification: E44, G21, G28

Keywords: bank lending, bank regulation, commercial real estate

${ }^{*}$ We thank Charles Calomiris, Chuck Morris, Nick Sly, Joe Van Walleghem, Jim Wilkinson, Susan Zubradt and seminar participants at the Federal Reserve Bank of Kansas City for helpful comments. We thank Tom Allard for kindly sharing the merger-adjusted Call Report data. All errors and omissions are our own. The views expressed herein are those of the authors and do not reflect the views of the Federal Reserve Bank of Kansas City or the Federal Reserve System.

${ }^{\dagger}$ Banking Research Department, Federal Reserve Bank of Kansas City, 1 Memorial Drive, Kansas City, MO 64198. E-mails: blake.marsh@kc.frb.org; rajdeep.sengupta@kc.frb.org

${ }^{\ddagger}$ Corresponding Author. 


\section{Introduction}

Since the 1970s, federal and local governments increasingly lowered barriers to entry for banks and other financial institutions thereby increasing bank competition [Claessens, 2009]. In comparison to the decades prior, the years following the liberalization process have arguably been marked by more bank failures and higher financial instability [Vives, 2011a]. While recognizing that banks are inherently fragile, it is important to understand the different ways in which competition can affect bank fragility, and ultimately, the stability of the financial system. Despite significant attention from policymakers and academics, there remain gaps in our understanding of how competition affects bank fragility [Vives, $2011 a, b]$

This study presents empirical evidence documenting the effect of deregulation and increased competition on the fragility of individual banks and the banking sector as a whole. Using U.S. banking data from 1990 to 2005, we examine how increased loan competition from large banking organizations (LBOs) led smaller community (CBOs) and regional banking organizations (RBOs) to increase their concentrations of commercial real estate (CRE) lending. ${ }^{1}$ The increase in CRE concentrations in CBOs and RBOs attracted regulatory scrutiny and, ex-post, is widely believed to be a principal cause of bank failures following the U.S. financial crisis [Friend, Glenos and Nichols, 2013; Bassett and Marsh, 2016]. The paper traces the build-up in CRE concentrations in smaller banks to the increase in large bank competition following interstate deregulation. In so doing, this paper presents evidence showing that large bank competition increased not only the fragility of smaller regional and community banks, but the banking sector as a whole.

Understanding the mechanisms through which pre-crisis CRE loan concentrations increased and their effect on the subsequent market collapse is paramount for addressing financial stability concerns [Rosengren, 2017]. Indeed, just prior to the crash, all three U.S. regulatory agencies jointly issued interagency guidance in December 2006 which reflected their concerns about the rising concentrations. ${ }^{2}$ In later analysis, Friend et al. [2013] find that "31 percent of all commercial banks in 2006 exceeded at least one of the

\footnotetext{
${ }^{1}$ We define three distinct BHC groups in terms of their real total domestic banking assets at the holding company level measured in 2009 dollars. We define CBOs as BHCs with real assets less than $\$ 10$ billion, RBOs as BHCs with real assets greater than $\$ 10$ billion but less than $\$ 50$ billion, and LBOs as BHCs with at least $\$ 50$ billion in real assets.

2 "Concentrations in Commercial Real Estate Lending, Sound Risk Management Practices", 71 Federal Register 238 (December 12, 2006), pp. 74580-74588 (www.occ.gov/news-issuances/ federalregister $/ 71 \mathrm{fr} 74580 . \mathrm{pdf})$
} 
concentration levels specified in the supervisory criteria." They find that banks exceeding just the construction loan criteria, "accounted for an estimated 80 percent of the losses to the Federal Deposit Insurance Corporation insurance fund from 2007 to 2011."

We trace the rise in CRE concentrations for CBOs and RBOs to increased LBO competition which, in turn, was facilitated by deregulation. In the late 1970s and early 1980s, most U.S. states still prohibited banking across state lines [Strahan, 2003]. As a result, the U.S. banking landscape was dominated by thousands of small community banks operating locally [Kane, 1996]. This was followed by a prolonged period of deregulation that led some, typically larger, banks to consolidate and expand their geographic footprint, while others continued to operate locally [Janicki and Prescott, 2006]. Initially, the predominant vehicle of entry and expansion was the holding company, which acquired out-of-state banks. But while the BHC undertook entry and acquisition decisions, loan portfolio decisions were actively managed at the bank level. Accordingly, we examine the effect of LBO entry and LBO competition on loan portfolios of local banks (i.e., banks of CBOs and RBOs that operated in the market prior to LBO entry, hereafter "local banks").

A local bank's market is defined as the county or counties in which the bank operates a branch. Large bank entry occurs with an LBO acquiring (or setting up) a (new) branch in any of the counties in the local bank's market. Our measures of LBO competition include the level and concentration of deposits that the LBO books at its branches in the local bank's market. The variables of interest are bank-level loan portfolio changes of the local bank upon LBO entry. A bank-level analysis also allows us to control for the bank's financial characteristics and market conditions for the counties in which the local bank operates.

The key finding of this paper is that local banks significantly increase the share of CRE lending in their loan portfolio upon LBO entry (and increased LBO competition). The results also show that, when faced with LBO competition, local banks also lower their share of retail lending after accounting for bank and market factors. These include a lower share of residential real estate (RRE) loans, consumer loans, and non-credit card loans. On the other hand, we do not observe any noticeable changes in commercial and industrial (C\&I) and credit card loan categories.

Our principal hypothesis is not without endogeneity concerns. Alternative explanations can be drawn as to how profitable local lending opportunities and economic conditions can drive loan portfolio choices of local banks together with LBO entry and competition. However, our hypothesis does not distinguish between alternative motives behind the local 
banks' switch from retail to CRE lending.

We address the endogeneity concern of local market factors using distance between a bank and any LBO as an instrumental variable (IV). In every period, the IV is the minimum distance between a local bank's main office and any LBO branch in the U.S. This distance measure is negatively correlated with LBO competition faced by local banks. For distance to be a valid instrument, it would have to affect the local banks portfolio choice only through its effect on LBO activity. We argue that this exclusion restriction is satisfied for our sample of local banks because the local bank is unlikely to significantly change its portfolio merely due to the threat of entry from an LBO (as would be plausible if an LBO set up a branch in a neighboring county). A large body of theoretical and empirical work on relationship lending argues that in comparison to large banks, small banks substantially rely on lending relationships with their clients (Petersen and Rajan [1995], Berger, Miller, Petersen, Rajan and Stein [2005]; see also Boot [2000], Gorton and Winton [2003] and references therein). We find it unlikely that a small bank would forgo lending opportunities with an arguably captive local customer base under the threat of entry ([Broecker, 1990; Sharpe, 1990]). The results from the IV regressions are similar to those mentioned above.

An important implication of our result is the increased sectoral concentration of loans for local banks facing LBO competition. In our sample, we observe increased CRE concentrations driven significantly by LBO competition. Needless to say, this has implications for CRE asset valuations and increased lending based on those valuations. At the same time, increased concentrations by themselves have implications for financial stability because they leave banks vulnerable to sector-specific shocks. What is also important here is that, while local banks individually make portfolio choices, overall concentration for the group of CBOs and RBOs increase. Combined with rising asset valuations this has important systemic stability implications not just for local banks as a group but LBOs exposed to CRE lending in other markets as well.

\section{$1.1 \quad$ Related Literature}

Our paper is related to a wide body of theoretical and empirical work on bank competition and fragility. It is important to note that while it is not the source of fragility in banks, competition can affect bank fragility in a variety of ways [Vives, 2011a]. In theory, bank competition can increase fragility by raising deposit rates [Rochet and Vives, 2004; 
Goldstein and Pauzner, 2005], eroding charter values [Keeley, 1990], and exacerbating the winner's curse problem [Broecker, 1990; Sharpe, 1990]. On the other hand, bank competition could also reduce fragility by offering better terms, thereby increasing borrower payoffs and improving asset quality [Caminal and Matutes, 2002; Boyd and De Nicolo, 2005]. In short, the result of lender competition on bank fragility remains an important empirical question.

A key feature of this study on loan competition is lender heterogeneity. A significant volume of empirical work finds that lender heterogeneity is important to loan outcomes. Among others, Berger et al. [2005] argue that "[s]mall banks are better able to collect and act on soft information than large banks" and they tend to rely more on lending relationships [Boot, 2000]. In contrast, large banks tend to adopt a more transaction or fee-based approach to lending [Cole, Goldberg and White, 2004].

In light of this, theoretical work has examined the outcome for entry and competition between heterogeneous lenders [Boot and Thakor, 2000; Dell'Ariccia and Marquez, 2004; Sengupta, 2007]. These theories predict that competition between better informed local incumbent lenders and low-cost larger entrants tends to exacerbate market segmentation. Incumbents struggle to compete on pricing in low-risk market segments and tend to focus on relatively higher risk segments where they can leverage their informational advantage by screening loan applicants. Our results lend support to the predictions of these theories. We find that local banks tend to lose market share in low-risk, transactions-based retail lending segments such as residential mortgages and consumer loans (Berger et al., 2017). On the other hand, they leverage their knowledge of the local market in focusing on relatively riskier segments such as CRE.

Our study is also related to a large strand of the empirical banking literature on the effects of deregulation in banking. While this literature examines the impact of deregulation on economic outcomes [Jayaratne and Strahan, 1996, 1998; Black and Strahan, 2002; Cetorelli and Strahan, 2006; Huang, 2008; Kerr and Nanda, 2009, 2010; Rice and Strahan, 2010; Amore, Schneider and Žaldokas, 2013; Chava, Oettl, Subramanian and Subramanian, 2013; Favara and Imbs, 2015; Michalski and Ors, 2012] and large banks [Goetz, Laeven and Levine, 2013; Levine, Lin and Xie, 2016; Jiang, Levine and Lin, 2016], few studies have examined the impact on local bank portfolios [Berger, Demsetz and Strahan, 1999]. More recent work has focused on the impact of deregulation on small-business lending [Black and Kowalik, 2016] and non-bank lenders [Chu, 2016]. We add to this literature by examining the effect of deregulation and large bank competition on the portfolios of small local banks. 
The remainder of the paper is structured as follows: Section 2 reviews trends in bank consolidation and asset concentration over the last two decades and discusses the related literature. Section 3 discusses the data used in the analysis. Sections 4 and 5 present the empirical strategy, identification assumptions, and results of the tests. Section 6 offers some concluding thoughts and directions for future research.

\section{Background}

Bank branching was restricted both within and across state borders prior to the 1970s. Over the next four decades, branching restrictions were relaxed in one form or another [Kroszner and Strahan, 2014]. Intra- and interstate reforms and federal deregulation prompted a period of consolidation in the banking industry both within and across states, primarily through merger and acquisition (M\&A) activity (figure 1a). During this consolidation wave, LBOs expanded geographically and entered markets previously served only by local banks. As a result, banking assets gradually became concentrated at LBOs while the number of smaller banks declined [Janicki and Prescott, 2006]. Indeed, McCord and Prescott [2014] observe (p.27) that banking industry consolidation "starts around 1990 and continues until the financial crisis." Accordingly, this study focuses on the period of LBO expansion from 1990 to 2005. This section presents the historical background to LBO expansion and the manner in which LBO competition increased for local banks.

\subsection{Holding Companies and Interstate Banking}

In the early-1980s, restrictions on statewide branching varied widely across states. However, banks were often able to circumvent these restrictions through the use of intrastate, multibank BHC operations. ${ }^{3}$ Over time, nearly all states permitted BHCs to convert offices of subsidiary banks within the state (existing or acquired) into branches of a single bank [Kroszner and Strahan, 1999]. In this way, intrastate consolidation facilitated an increase in bank size and began a multi-decade decline in the number of multibank BHCs starting in the late 1980s (figure 1b).

Interstate deregulation of banking began around the mid-1980s after New York and

\footnotetext{
${ }^{3}$ For example, in 1980, 36 states prohibited unrestricted state-wide branching, but three of those states did allow branching through M\&A activity. In contrast, only 13 states prohibited multi-bank holding company operations which allowed banking organizations to utilize the holding company structure to operate in several locations within the state. See Kroszner and Strahan [1999] and Kane [1996] for more details.
} 
Alaska followed Maine (which deregulated in 1978) and allowed out-of-state banks to acquire local banks on a reciprocal basis [Kroszner and Strahan, 1999]. The number of states that allowed interstate banking increased steadily through the late-1980s, often via regional reciprocal arrangements [Amel, 1993]. Indeed, while intrastate deregulation led to a decline in multi-bank BHCs in the late-1980s (figure 1b), the number of BHCs that operated banks in multiple states increased over the same period (figure 1c). However, while many BHCs quickly responded to intrastate deregulation by consolidating banks within the state, they were slow to take advantage of interstate banking reforms [McLaughlin, 1995]. McLaughlin [1995](p. 2) finds that those BHCs that did enter new states during this period typically "acquired banks in neighboring, rather than distant, states". Between 1988 and 1993, "nearly 75 percent of all first-time entries represented moves into a neighboring state" [McLaughlin, 1995]. These considerations are important for our use of distance as an IV in Section 5.

\subsection{LBO Expansion}

We find that LBO entry into new markets followed a pattern similar to that of other BHCs. Over time, LBOs increased in number (figure 1d) and expanded their geographic footprint. In 1990, there were only 14 LBOs operating on the coasts with the densest branch networks located in the DC-New York-Boston and Los Angeles-San Francisco corridors (figure 2a). By 2005, the number of LBOs rose to 27 and their presence increased in non-major metro areas, particularly in the Southeast and Midwest. Cities such as Nashville, Memphis, Birmingham, Kansas City, St. Louis, and Denver, which had little or no LBO presence in 1990, had a notable number of LBO branches by 2005 (figure $2 b$ )

The pattern of LBO expansion and consolidation during this period is best explained in terms of the increase in out-of-state branches. Figure 3 defines out-of-state branches as the number of branches in states outside a bank's or BHC's respective headquarter location. In 1985, there were just 63 multi-state BHCs (figure 1c) operating more than 3,000 out-of-state branches (figure 3). The number of multi-state BHCs, and their out-ofstate branches, increased throughout the late 1980s and early 1990s. Figure 3 also shows that while out-of-state branches of BHCs increased through the mid-1990s, the number of out-of-state branches held by their banking subsidiaries remained low. As a result, nearly all of the early interstate expansion of banking activity occurred using the holding company structure. Put differently, it was multi-bank BHCs, and not the bank, that was the market 
entry vehicle.

The Interstate Banking and Branching Efficiency Act (IBBEA) of 1994 allowed BHCs to acquire banks nationwide, subject to certain limitations [Johnson and Rice, 2008]. The IBBEA also allowed BHCs to convert their branches in various states into branches of a single interstate bank beginning in 1997. Multi-state BHCs took this opportunity to consolidate. Accordingly, the number of multi-state BHCs peaked in 1997 and has declined steadily thereafter (figure 1c). However, the number of out-of-state subsidiary bank branches increased sharply around this time (figure 3). Indeed, the sharp increase in out-of-state bank branches following the IBBEA is largely a result of multi-state BHCs consolidating into a single branch network under a multi-state bank rather than a sudden increase in their geographic footprint. Figure 3 also suggests that the pattern of expansion for all banks and BHCs was mostly driven by LBOs and their subsidiary banks. In summary, figure 3 captures the consolidation of banking activity into LBOs and the geographic expansion of LBOs during this period.

\subsection{Local Banks Facing LBO competition}

While LBOs expanded nationwide, a significant number of smaller banks chose to operate locally. Although M\&A activity was common within these local bank populations, the key distinction between these banks and LBOs lies in their asset size distribution and the geographical spread of their operations, as measured in terms of their branching network. Over the years in our sample, the median LBO has $\$ 89$ billion in real assets with branches in 110 counties. In contrast, the median RBO has $\$ 19$ billion in real assets with branches in 35 counties whereas the median CBO has $\$ 83$ million in assets and branches in just a single county.

Figure 4 charts the share of local banks operating a branch in a county where the LBO also operates a branch. The share is calculated separately for branches of the BHC (bold line) as well as its subsidiary banks (dotted line). As shown in figure 4, there is little difference whether the increase in competition is tabulated using the branches of the bank or its holding company. Still, in the analysis below, we examine the impact of LBO competition on the loan portfolios of individual banks. There are two reasons for focusing on the bank and not the BHC. First, individual lending decisions are typically made at the level of the bank and not its holding company. Second, focusing on the bank allows for a more granular analysis and helps to better identify the local effects of LBO competition. 
With LBO entry and expansion in different parts of the country, figure 4 shows that the share of local banks facing LBO competition increased from about 10 percent in 1985 to more than 80 percent in 2005. Over the same period, there has been a notable change in the loan portfolios of local banks. CRE loans as a share of total assets at local banks increased considerably since the mid-1980s (figure 5). However, CRE loan shares remained relatively unchanged for LBO banks.

Interestingly, CRE loan shares of local banks continued to increase, peaking around 2007. However, on December 6, 2006 all three federal regulatory agencies issued supervisory guidance concerning the increasing concentrations of CRE loans. Bassett and Marsh [2016] find that this regulatory guidance prompted banks to rebalance their loan portfolios away from CRE lending. Therefore, this study examines the effect on local bank loan portfolios until 2005, before any real or anticipated effects of the regulatory guidance.

To summarize, we examine the effects of LBO entry on local bank portfolios from 1990 to 2005. Since BHCs were the vehicle of entry, our data uses entry dates of the holding company and not the bank. On the other hand, we examine the effect of LBO competition on local bank (not BHC) portfolios.

\section{Data}

Ideally, one would want loan level data with location information to determine local market competition. However, data of this type for local banking organizations are limited to RRE collected through the Home Mortgage Disclosure Act (HMDA), a subset of newly originated small business loans through Community Reinvestment Act (CRA) data collection, and bank branch deposit holdings. As with most other studies on local bank competition, our competition measures use deposit data as a proxy for loan competition. The FDIC's Summary of Deposits (SOD) data report both the location and deposit holdings of all branches operated by depository institutions in the United States as-of June of each year. We use the reported location coordinates (latitude and longitude) to map each branch to a U.S. county using the 2014 Tiger/LINE shapefile definitions. ${ }^{4}$ The mapping ensures that changes in a branch's county location are due to openings, closings, or moves rather than changes in the county border definitions. In other words, the geographic boundaries are held constant over time.

\footnotetext{
${ }^{4}$ The Tiger/LINE shapefiles can be found on the U.S. Census Bureau's website: https://www.census . gov/geo/maps-data/data/tiger-line.html
} 
Competition measures based on deposits may under- or overstate the true level of loan competition. ${ }^{5}$ To allay these concerns, we consider bank branches as an alternative measure of a bank's ability and willingness to lend locally. Moreover, under the Community Reinvestment Act, banks are required to lend at least a portion of locally raised deposits in that market. Taken together, it is likely that competition measures based on deposits and loans are highly correlated, on average, for our sample of local banks.

In view of the previous discussion, we construct three measures of LBO activity to determine the level of LBO competition faced by local banks. The first measure is total county-level deposits held by LBOs. The second and third measures are the HerfindhalHirschman indices based on marketshares of county-level, LBO deposits and branches, respectively. The HHI indices are calculated according to equation 1 where $s_{i, c, t}$ is LBO $i$ 's deposit or branch share in county $c$, for year $t$. HHI indices are used because they are the preferred measure of competition in most banking analyses [Rhodes, 1993].

$$
H H I_{c t}^{L B O}=\sum_{i=1}^{N} s_{i, c, t}^{2}
$$

To examine changes in bank portfolios, the regression analysis uses local bank loan portfolio measures as dependent variables and LBO activity measures as the explanatory variables. In addition, we use two sets of control variables: a set of bank-level controls and a set of controls for the local bank's market conditions. We use the local bank's prior loan growth, net interest margins (NIMs), delinquency and charge off rates, and the Tier 1 leverage ratio to control for prior lending activity, profitability, risk, and capitalization, respectively. These variables are drawn from the FFIEC's Reports of Condition and Income (Call Reports) that provide quarterly, bank-level financial information. Growth rates and income items are adjusted for bank mergers according to the methodology described in English and Nelson [1998]. Loan growth rates are trimmed at the 1st and 99th percentile to account for large loan acquisitions that are not otherwise captured by merger adjustments and data reporting errors. The set of market controls include county-level measures of population and building permits (on new, privately-owned residential construction) from

\footnotetext{
${ }^{5}$ Using deposit data as proxy for loan competition is not without its problems. For one, deposits booked at a given branch can be used to make loans at any other branch in the banks network (Gilje, Loutskina and Strahan [2016]). In this case, branch deposits would understate the true level of competition. On the other hand, while banks typically book deposits in the branch where they were collected, many business or municipal deposits are often booked at a central or headquarter location. In this case the true level of competition maybe overstated by deposit measures.
} 
the U.S. Census Bureau. We also include county-level per capita income from the Bureau of Labor and Statistics' Quarterly Census of Employment and Wages. When the data are not annual, the measures reported closest to June of each year are used.

We define a local bank's market to be the set of counties in which the bank operates branches. Accordingly, county-level variables, including the HHI measures described above, are weighted by the local bank's "exposure" to each county according to equation 2 . The weights, denoted by $w_{i, c, t}$, are the share of branches held by bank $i$ in county $c$ for year $t$. These weights sum to unity so the resulting variable is a bank-specific, branch-weighted average of local market controls and LBO competition that vary annually. This weighting scheme has been used elsewhere in the literature [Cetorelli and Strahan, 2006; Chakraborty, Goldstein and MacKinlay, 2013; Glancy, 2015; Bassett and Marsh, 2016]. In view of our earlier discussion that underlies the importance of branches to local banking activity, we use the share of branches, and not deposits, as weights in the following equation.

$$
y_{i, t}=\sum_{c=1}^{N} w_{i, c, t} * y_{c, t} \quad \text { s.t. } \quad \sum_{c=1}^{N} w_{i, c, t}=1
$$

The resulting data form a panel indexed by bank and year. Local banks that operate in markets that never experienced LBO entry and those that operated in markets with LBO branches prior to 1990 are excluded from the sample. As a result, our sample consists of local banks that experienced LBO entry after 1990. Our sample period starts in 1990, the first date for which we have county-level macroeconomic controls, and ends in 2005, the year just before the CRE supervisory guidance was issued for comment. Summary statistics are presented in table 1.

\section{Effects of Increased LBO Market Activity}

We begin our analysis by examining how local bank loan portfolios changed with LBO entry. As a first step, we examine changes in loan portfolios prior to and following entry without accounting for the level of LBO market activity. The next set of regressions measure these changes accounting not only for the level of LBO activity but also other bank and market controls. 


\subsection{Before and After LBO Entry}

Entry is indicated by a change in the weighted LBO deposits measure described in section 3 from zero to a non-zero level. We estimate equation 3 to examine the dynamics of lending behavior around LBO entry. This specification provides some insight into the longer run effects of LBO entry on local bank portfolio changes.

$$
\text { Loan } \text { Share }_{i, t}=\alpha_{i}+\tau_{t}+\sum_{q=-5}^{5} \beta_{t+q} D_{i, t+q}+\varepsilon_{i, t}
$$

Loan Share ${ }_{i, t}$ is a measure of local bank loans as a share of total assets and $\alpha_{i}$ and $\tau_{t}$ are bank and time fixed effects, respectively. The variables $D_{i, t+q}$ are indicator variables for year $t+q$ after LBO market entry. The coefficients $\beta_{t+q}$ measure the changes in local bank loan shares (in each loan category) $q$ years before and after LBO entry. Following Kerr and Nanda [2009, 2010], all periods five years prior to entry and five years after entry are included in the -5 and +5 indicators, respectively. We omit the indicator for market entry $\left(D_{i, t}\right)$. These regressions tell us how average loan shares in the five years before and after LBO market entry compared to those prevailing at the year of LBO entry.

Figure 6 plots the estimated coefficients (along with 95 percent confidence intervals) in equation 3 for the four core loan categories in Call Report data: CRE, RRE, C\&I and consumer loans. Figure 6(a) shows that prior to LBO market entry, CRE shares at local banks were not statistically different from those at the reference year of LBO entry (shown as period 0 on the graph). However, these same local banks increased their average CRE loan shares in most of the subsequent five years after LBO entry. Overall, we estimate a percentage point increase in CRE loan shares in the five years following LBO entry, but no change in the five years prior to entry.

Interestingly, there appears to be a significant increase in RRE loan shares of local banks prior to LBO entry (figure 6(b)). These estimates lend support to our endogeneity concerns about LBO entry: it appears that LBOs selected markets with increasing opportunities for RRE lending. We estimate that RRE shares of local banks remained unchanged (relative to the RRE share at the year of entry) in the years immediately following LBO entry before starting to decline in later years. Shares of C\&I and consumer lending show little to no significant change in the five years prior to or in the five years following LBO entry (figure $6(\mathrm{c})$ and $6(\mathrm{~d}))$. 


\subsection{Changes in LBO Activity}

Next, we examine how bank loan portfolios change with LBO activity after controlling for variations in bank and local market conditions. We estimate the fixed effects specification in equation 4 with separate regressions for each of the three measures of LBO activity (as described in section 3):

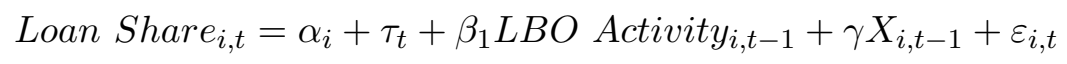

Loan shares, bank and year fixed effects are denoted by the same variables as in equation 3. The coefficient of interest is $\beta_{1}$, which estimates how bank loan shares in a particular category change with increased LBO activity in the previous year. The matrix $X_{i, t-1}$ represents the set of predetermined (lagged one period) bank and market controls described in Section $2 .^{6}$

The results for CRE loan shares are shown in table 2. Each column shows the estimate for $\beta_{1}$ using one of the three LBO activity measures as denoted by the column header. HHI and deposit level measures are log transformed to account for their highly skewed distributions. Across all competition measures, an increase in LBO activity is associated with an increase in the share of local bank CRE loans. These estimates confirm the results in 6(a) that show local banks increasing CRE shares in their portfolio following LBO entry. The difference here is that these estimates account for LBO activity, financial ratios, and market factors that could also change bank loan portfolios.

These findings are robust to the measure of activity used with the largest coefficient on the log level of the county-weighted HHI measure based on LBO deposits. On average, a one percent increase in the market-specific level of the LBO deposit HHI is associated with a 9 basis point increase in CRE loans as a share of total assets. Similarly, a one percent increase in the localized HHI measure based on LBO branch shares is associated with an 8 basis point increase in CRE loan shares. A similar one percent increase in the level of LBO deposits in a bank's local operating market is associated with about a 5 basis point increase in CRE loan shares in the following year. Overall, the estimates suggest that a one standard deviation increase in LBO competition measures lead to an initital quarter percent increase in CRE shares at local banks in the following year.

Table 3 estimates how local banks' non-CRE loan shares change with increased LBO

\footnotetext{
${ }^{6}$ Alternative specifications that include both predetermined and contemporaneous county level controls yield similar results.
} 
activity in their local markets. While such an analysis is somewhat subject to an adding up constraint, the demoninator of the share variables is total assets so this is less of a concern for the analysis. For example, a local bank facing increased comeptiton for RRE loans could substitute their RRE loan exposure with mortgage-back securities to achieve a similar risk profile and portfolio composition. The results indicate that higher LBO activity levels are also associated with lower shares of RRE and consumer loans, particularly the noncredit card loan segment. Both RRE and consumer loan shares are estimated to decline about 15 basis points in the year following a one standard deviation increase in LBO competition. The estimated coefficients for C\&I and credit card loan shares, however, are not statistically significant. Therefore, it is difficult to associate changes in these loan categories with changes in LBO activity. All of these findings are robust to the various measures of LBO activity, using a sample of CBO banks only, and including both lagged and contemporaneous local market factors (as in Favara and Imbs [2015]).

As an alternative explanation, our results could be affected by selection issues. If LBOs target banks for acquisition that have a high share of RRE loans (low share of CRE loans) in their portfolio, then it is plausible that our results are driven by their exclusion from the sample of local banks post entry. To rule this out, we form a subsample of local banks that were never acquired throughout the years in our sample. Figure 7 plots the CRE loan shares for this balanced panel of active local banks from 1990 to 2005. CRE loan shares for this subsample increased from around 10 percent of assets in 1990 to over 25 percent of assets in 2005, similar to that shown in figure 5. Clearly, the increase in CRE loan shares for local banks is driven by factors other than issues of LBOs selection of banks as targets for acquisition.

\section{$5 \quad$ IV Estimation Using Bank Branch Distance}

The previous analysis suggests a positive association between increased LBO competition and CRE lending by local banks in their operating markets. The results also suggest a negative association between LBO competition and retail lending segments, namely, RRE and non-credit card consumer lending. These results provide empirical support for theories of entry and competition described in section 2. The finding that local banks reduced household loan shares complements the results of Favara and Imbs [2015] and Berger, Irresberger and Roman [2017] who suggest that large banks that expanded during the branching deregulation period made a larger quantity of RRE and consumer loans, 
respectively.

Despite the theoretical and empirical support for our preliminary results, the LBO competition measures prompt endogeneity concerns. Alternative explanations can be drawn as to how profitable local lending opportunities and economic conditions can drive loan portfolio choices of local banks together with LBO entry and competition. We find some evidence for this in our results shown in figure 6(b) where RRE loan shares of local banks were increasing prior to LBO entry. Given that the observed loan shares are an equilibrium outcome, these results suggest a simultaneity concern.

To address these endogeneity issues, we use an instrumental variables approach to identify the effect of LBO activity on local bank loan shares. In every period, the IV is the minimum distance between the local bank's main office and any LBO branch in the U.S. We choose to measure the distance from a local bank's main office, rather than using bank branch locations, because local banks are less likely to move their main office in the face of competition. In first stage regressions (not shown), the distance measure is negatively correlated with LBO competition faced by local banks. In this way, the instrument measures the likelihood of LBO entry ("intent to treat" or "threat of entry") into a local bank's market.

For distance to be a valid instrument, it must affect the local bank's portfolio choice only through its effect on LBO activity. We argue that this exclusion restriction is satisfied for our sample of local banks because the local bank is unlikely to significantly change its portfolio merely due to the threat of entry from an LBO. In essence, we assume that local banks do not rebalance their loan portfolios in response to competitive threats from larger rivals, but respond to competition only after the larger rival has entered the local market and shown an ability to out-compete the smaller banks for their "captive" customer base.

While this appears to be a strong assumption for most other businesses, we argue that it is plausible and likely given knowledge of local banks and their operations. A large body of theoretical and empirical literature on relationship lending argues that in comparison to large banks, local banks rely significantly on lending relationships with their clients (see Boot [2000], Gorton and Winton [2003] and references therein). For example, Sharpe [1990] argues that over time, these banks are able to retain relationship banking customers due to informational frictions that prevent borrowers from signaling their quality to other lenders. In other words, over time, relationship-based borrowers become "informationally captured". Due to the potential for extracting rents from these relationship customers, banks will enter into initial contracts that generate expected losses, but potentially have 
high future payoffs [Petersen and Rajan, 1995; Sharpe, 1990]. Under this relationship banking model, local banks would be unwilling to relinquish their customer base on the basis of competitive threats. Instead, as our theoretical and empirical narrative suggests, due to their funding and technological advantages, large banks were successful in pulling these relationship-based customers away from their local rivals.

The IV regression results for CRE loan shares are shown in table 4. The IV regressions show that CRE loans shares are positively and significantly related to the instrumented LBO activity measures. The effect is larger than that found in the simple fixed effect OLS regressions. Given a one percent increase in LBO activity as measured by HHI, local bank CRE loan shares rise about 20 basis points. Given a one percent increase in LBO deposits, local bank CRE shares increase about 10 basis points. The coefficient estimates suggest that local bank CRE loan shares rise about 65 basis points given a one standard deviation increase in the LBO measures.

The instrumented non-CRE loan share estimates are shown in table 5 . These results also confirm the earlier finding that RRE and non-credit card consumer loan shares at local banks are negatively related to LBO market activity. Similar to the non-instrumented fixed effects regression, the effect on C\&I loan shares is not statistically different from zero. Again, the instrumented results are larger than the non-instrumented results presented in table 3. RRE shares in the instrumented regressions are estimated to decline about 40 basis points one year after a one standard deviation rise in LBO competition. Consumer loan shares are expected to decline a bit more modestly, only about 25 basis points, following such an increase. This difference provides further support for the idea that residential mortgages were the most adversely affected segment of local bank portfolios following an increase in LBO competition.

Overall, the results suggest that increased LBO competition is associated with buildups of CRE portfolios and, to some degree, changes in other loan portfolio shares. These findings are consistent with the aggregate level marketshare changes shown in figure 5 . The regressions provide additional support to the idea that competitive changes in local markets, spurred by large bank entry, led to portfolio shifts at smaller banking institutions.

\section{Conclusion}

The theoretical literature on bank competition has shown that lender heterogeneity can unwittingly exacerbate market segmentation. Our results find strong support in the pre- 
dictions of these theories. In our sample of U.S. banks observed from 1990 to 2005, we find that the pre-crisis build-up in CRE concentrations of local banks can be traced to LBO entry and competition. Local banks struggle to retain their clients in low-risk retail segments prompted them to focus on riskier segments of the market such as CRE, where they could leverage their local information advantage. Competition from LBOs was a significant factor in the build-up of CRE concentrations in local CBO and RBO banks.

The key result has important implications for CRE asset valuations and increased lending based on those valuations. At the same time, increased concentrations by themselves have implications for financial stability because they leave banks vulnerable to sectorspecific shocks. It is likely that the increased supply of credit from local banks into CRE may have fueled the sustained increase in CRE asset valuations leaving local bank portfolios increasingly vulnerable to a downturn. What is also important here is that, while local banks individually make portfolio choices, overall concentration for the local bank group increase. Combined with asset valuations this has important systemic implications for financial stability not just for the local banks but LBOs exposed to CRE lending in other markets as well. 


\section{References}

Amel, Deal F. [1993], State Laws Affecting the Geographic Expansion of Commercial Banks. Mimeo.

Amore, Mario Daniele, Schneider, Cedric and Žaldokas, Alminas. [2013]. 'Credit Supply and Corporate Innovation', Journal of Financial Economics 109(3), 835-855.

Bassett, William F. and Marsh, W. Blake. [2016]. 'Assessing Targeted Macroprudential Financial Regulation: The Case of the 2006 Commercial Real Estate Guidance for Banks', Journal of Financial Stability, forthcoming.

Berger, Allen N, Demsetz, Rebecca S and Strahan, Philip E. [1999]. 'The Consolidation of the Financial Services Industry: Causes, Consequences, and Implications for the Future', Journal of Banking \& Finance 23(2), 135-194.

Berger, Allen N., Irresberger, Felix and Roman, Raluca A. [2017], Do Small Banks Alleviate Households' Financial Constraints? Surprising Evidence from the University of Michigan Surveys of Consumers. Mimeo, March 2017.

Berger, Allen N, Miller, Nathan H, Petersen, Mitchell A, Rajan, Raghuram G and Stein, Jeremy C. [2005]. 'Does Function Follow Organizational Form? Evidence from the Lending Practices of Large and Small Banks', Journal of Financial economics $76(2), 237-269$.

Black, Lamont and Kowalik, Michal. [2016], The Changing Role of Small Business Lending. Mimeo.

Black, Sandra E. and Strahan, Philip E. [2002]. 'Entrepreneurship and Bank Credit Availability', The Journal of Finance 57(6), 2807-2833.

Boot, Arnoud WA. [2000]. 'Relationship Banking: What Do We Know?', Journal of financial intermediation 9(1), 7-25.

Boot, Arnoud WA and Thakor, Anjan V. [2000]. 'Can Relationship Banking Survive Competition?', The Journal of Finance 55(2), 679-713.

Boyd, John H and De Nicolo, Gianni. [2005]. 'The Theory of Bank Risk Taking and Competition Revisited', The Journal of finance 60(3), 1329-1343. 
Broecker, Thorsten. [1990]. 'Credit-Worthiness Tests and Interbank Competition', Econometrica 58(2), 429-452.

Caminal, Ramon and Matutes, Carmen. [2002]. 'Market Power and Banking Failures', International Journal of Industrial Organization 20(9), 1341-1361.

Cetorelli, Nicola and Strahan, Philip E. [2006]. 'Finance as a Barrier to Entry: Bank Competition and Industry Structure in Local U.S. Markets', The Journal of Finance $61(1), 437-461$.

Chakraborty, Indraneel, Goldstein, Itay and MacKinlay, Andrew. [2013], Do Asset Price Bubbles Have Negative Real Effects? Working Paper.

Chava, Sudheer, Oettl, Alexander, Subramanian, Ajay and Subramanian, Krishnamurthy V. [2013]. 'Banking Deregulation and Innovation', Journal of Financial Economics 109(3), 759-774.

Chu, Yongqiang. [2016], Banking Deregulation and Credit Supply: Distinguishing the Balance Sheet and the Competition Channels. Working Paper.

Claessens, Stijn. [2009], Competition in the Financial Sector: Overview of Competition Policies. IMF Working Paper WP/09/45.

Cole, Rebel A, Goldberg, Lawrence G and White, Lawrence J. [2004]. 'Cookie Cutter vs. Character: The Micro Structure of Small Business Lending by Large and Small Banks', Journal of financial and quantitative analysis 39(02), 227-251.

Dell'Ariccia, Giovanni and Marquez, Robert. [2004]. 'Information and Bank Credit Allocation', Journal of Financial Economics 72(1), 185-214.

English, William B. and Nelson, William R. [1998]. 'Profits and Balance Sheet Developments at U.S. Commercial Banks in 1997', Federal Reserve Bulletin 84, 391-419.

Favara, Giovanni and Imbs, Jean. [2015]. 'Credit Supply and the Price of Housing', The American Economic Review 105(3), 958-992.

Friend, Keith, Glenos, Harry and Nichols, Joseph B. [2013], An Analysis of the Impact of the Commercial Real Estate Concentration Guidance. Federal Reserve Board and Office of the Comptroller of the Currency. 
Gilje, Erik P, Loutskina, Elena and Strahan, Philip E. [2016]. 'Exporting Liquidity: Branch Banking and Financial Integration', The Journal of Finance 71(3), 1159-1184.

Glancy, David. [2015], Measuring Spatial Banking Competition. Working Paper.

Goetz, Martin R., Laeven, Luc and Levine, Ross. [2013]. 'Identifying the Valuation Effects and Agency Costs of Corporate Diversification: Evidence from the Geographic Diversification of U.S. Banks', The Review of Financial Studies 26(7), 1787-1823.

Goldstein, Itay and Pauzner, Ady. [2005]. 'Demand-Deposit Contracts and the Probability of Bank Runs', the Journal of Finance 60(3), 1293-1327.

Gorton, Gary and Winton, Andrew. [2003], Financial Intermediation, in Milton Harris George M. Constantinides and Ren'e M. Stulz., eds, 'Corporate Finance', Vol. 1, Part A of Handbook of the Economics of Finance, Elsevier, pp. 431552.

Huang, Rocco R. [2008]. 'Evaluating the Real Effect of Bank Branching Deregulation: Comparing Contiguous Counties Across U.S. State Borders', Journal of Financial Economics 87(3), 678-705.

Janicki, Hubert P. and Prescott, Edward Simpson. [2006]. 'Changes in the Size Distribution of U.S. Banks: 1960-2005', Federal Reserve Bank of Richmond Economic Quarterly 92(4), 291-316.

Jayaratne, Jith and Strahan, Philip E. [1996]. 'The Finance-Growth Nexus: Evidence from Bank Branch Deregulation', The Quarterly Journal of Economics 111(3), 639.

Jayaratne, Jith and Strahan, Philip E. [1998]. 'Entry Restrictions, Industry Evolution, and Dynamic Efficiency: Evidence From Commercial Banking', The Journal of Law and Economics 41(1), 239-274.

Jiang, Liangliang, Levine, Ross and Lin, Chen. [2016]. 'Competition and Bank Opacity', Review of Financial Studies 29(7), 1911-1942.

Johnson, Christian A and Rice, Tara. [2008]. 'Assessing a Decade of Interstate Bank Branching', Wash. \& Lee Law Review 65, 73. 
Kane, Edward J. [1996]. 'De Jure Interstate Banking: Why Only Now?', Journal of Money, Credit and Banking 28(2), 141-161.

Keeley, Michael C. [1990]. 'Deposit Insurance, Risk, and Market Power in Banking', The American Economic Review pp. 1183-1200.

Kerr, William R. and Nanda, Ramana. [2009]. 'Democratizing Entry: Banking Deregulations, Financing Constraints, and Entrepreneurship', Journal of Financial Economics 94(1), 124-149.

Kerr, William R. and Nanda, Ramana. [2010]. 'Banking Deregulations, Financing Constraints, and Firm Entry Size', Journal of the European Economic Association 8(23), $582-593$.

Kroszner, Randall S. and Strahan, Philip E. [1999]. 'What Drives Deregulation? Economics and Politics of the Relaxation of Bank Branching Restrictions', The Quarterly Journal of Economics 114(4), 1437.

Kroszner, Randall S and Strahan, Philip E. [2014], Regulation and Deregulation of the US Banking Industry: Causes, Consequences, and Implications for the Future, in 'Economic Regulation and Its Reform: What Have We Learned?', University of Chicago Press, pp. 485-543.

Levine, Ross, Lin, Chen and Xie, Wensi. [2016]. 'Spare Tire? Stock Markets, Banking Crises, and Economic Recoveries', Journal of Financial Economics 120(1), 81-101.

McCord, Roisin and Prescott, Edward Simpson. [2014]. 'The Financial Crisis, the Collapse of Bank Entry, and Changes in teh Size Distribution of Banks', Federal Reserve Bank of Richmond Economic Quarterly First Quarter, 23-50.

McLaughlin, Susan. [1995]. 'The Impact of Interstate Banking and Branching Reform: Evidence from the States', Current Issues in Economics and Finance 1(2), 1-5.

Michalski, Tomasz and Ors, Evren. [2012]. '(Interstate) Banking and (Interstate) Trade: Does Real Integration Follow Financial Integration?', Journal of Financial Economics 104(1), 89-117. 
Petersen, Mitchell A. and Rajan, Raghuram G. [1995]. 'The Effect of Credit Market Competition on Lending Relationships', The Quarterly Journal of Economics 110(2), 407.

Rhodes, Stephen A. [1993]. 'The Herfindahl-Hirschman Index', Federal Reserve Bulletin March, 188-189.

Rice, Tara and Strahan, Philip E. [2010]. 'Does Credit Competition Affect Small-Firm Finance?', The Journal of Finance 65(3), 861-889.

Rochet, Jean-Charles and Vives, Xavier. [2004]. 'Coordination Failures and the Lender of Last Resort: Was Bagehot Right After All?', Journal of the European Economic Association 2(6), 1116-1147.

Rosengren, Eric. [2017], Financial Stability: The Role of Real Estate Values. Speech to the Asia-Pacific High Level Meeting on Banking Supervision, Bali, Indonesia; March 22, 2017.

Sengupta, Rajdeep. [2007]. 'Foreign Entry and Bank Competition', Journal of Financial Economics 84(2), 502-528.

Sharpe, Steven A. [1990]. 'Asymmetric Information, Bank Lending and Implicit Contracts: A Stylized Model of Customer Relationships', The Journal of Finance 45(4), 1069-1087.

Strahan, Philip E. [2003]. 'The Real Effects of U.S. Banking Deregulation', Federal Reserve Bank of St. Louis Review 85(4), 111-128.

Vives, Xavier. [2011a], Competition and Stability in Banking, in 'Monetary Policy Under Financial Turbulence', pp. 455-502. Proceedings of the Annual Conference of the Central Bank of Chile.

Vives, Xavier. [2011b]. 'Competition Policy in Banking', Oxford Review of Economic Policy 27(3), 479-497. 


\section{Charts}

Figure 1: Annual Bank Counts

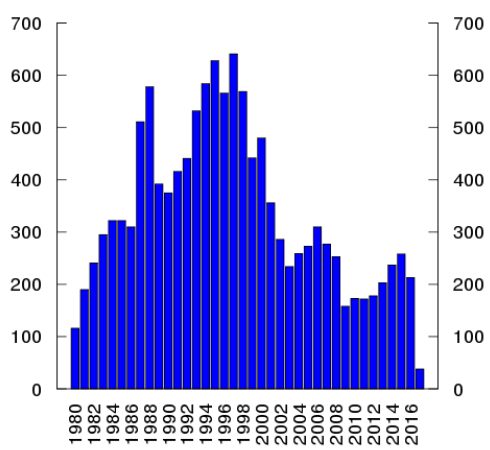

(a) Annual Bank Mergers

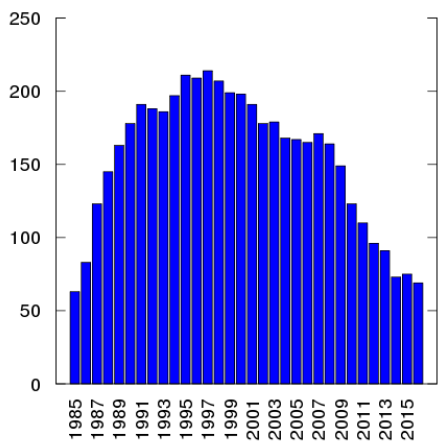

(c) Multistate BHCs

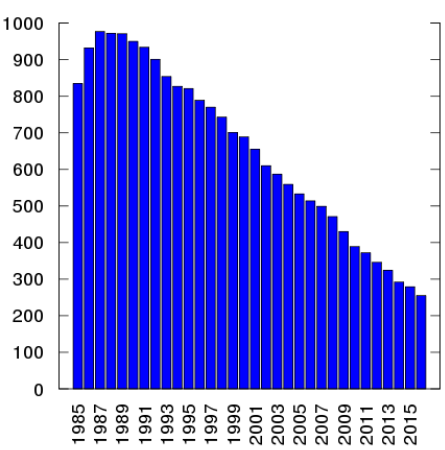

(b) Multibank BHCs

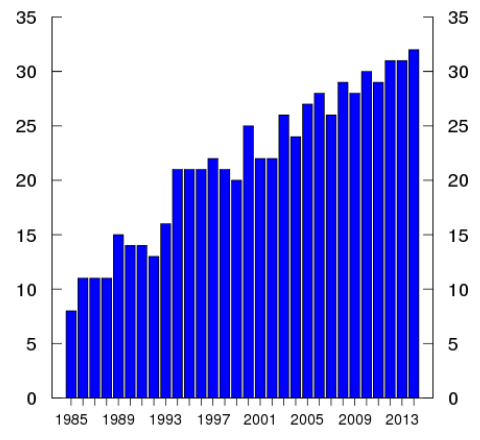

(d) LBO Count 
Figure 2: Large Banking Organization Branch Locations

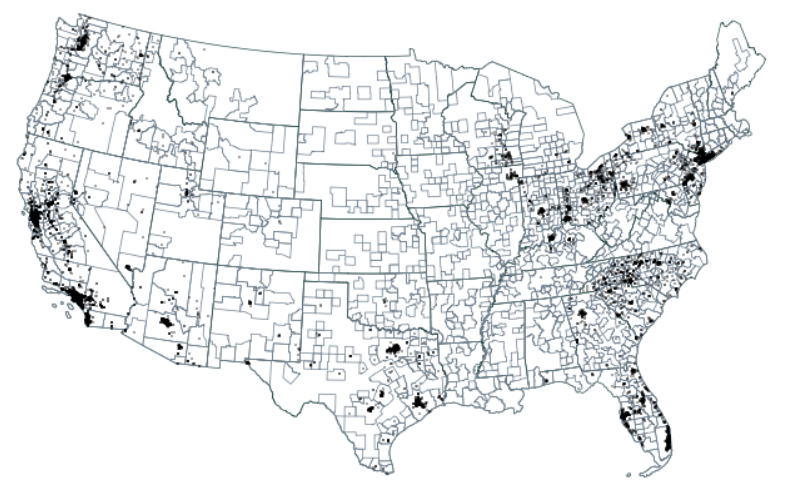

(a) June 1990

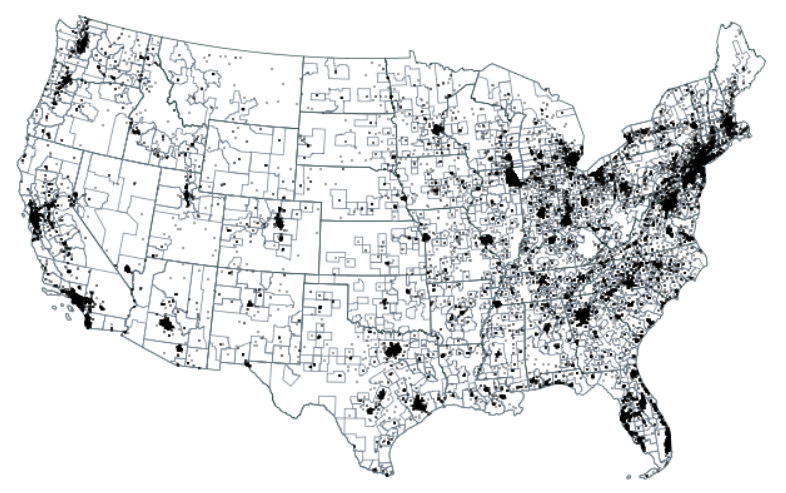

(b) June 2005

Figure shows branch locations of bank holding companies with consolidated banking assets of $\$ 50$ billion or more (in 2009 dollars) as-of June 1990 and 2005, respectively. State boundaries are shown in black while Census Designated CBSAs as-of 2014 are shown in gray.

Source: FFIEC Call Reports and FDIC's Summary of Deposits. 
Figure 3: Out Of State Branches

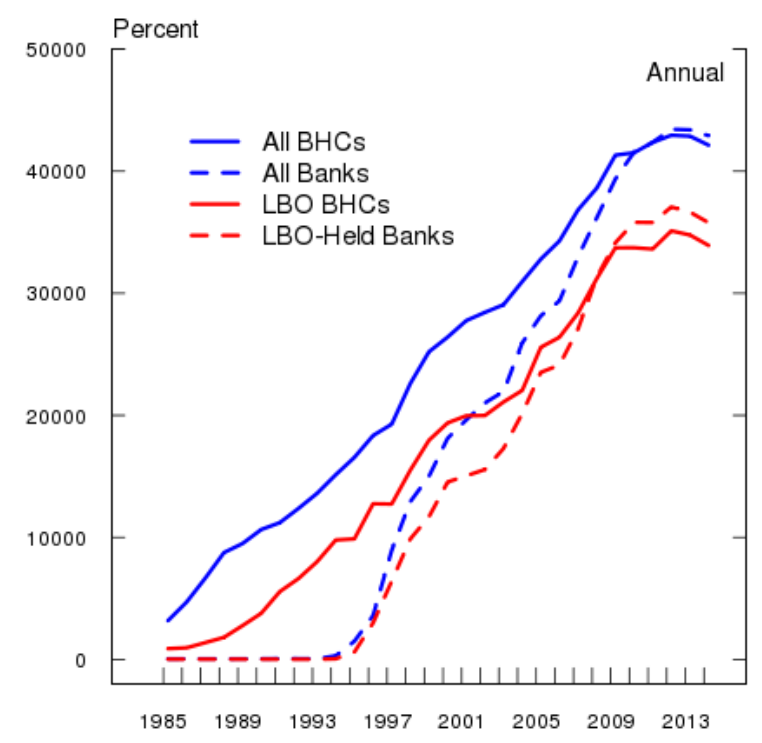

Figure shows number of out-of-state branches based on BHC/bank headquarters location in each year. Source: FFIEC Call Reports and FDIC's Summary of Deposits. 
Figure 4: Share of CBOs and RBOs Facing LBO Competition

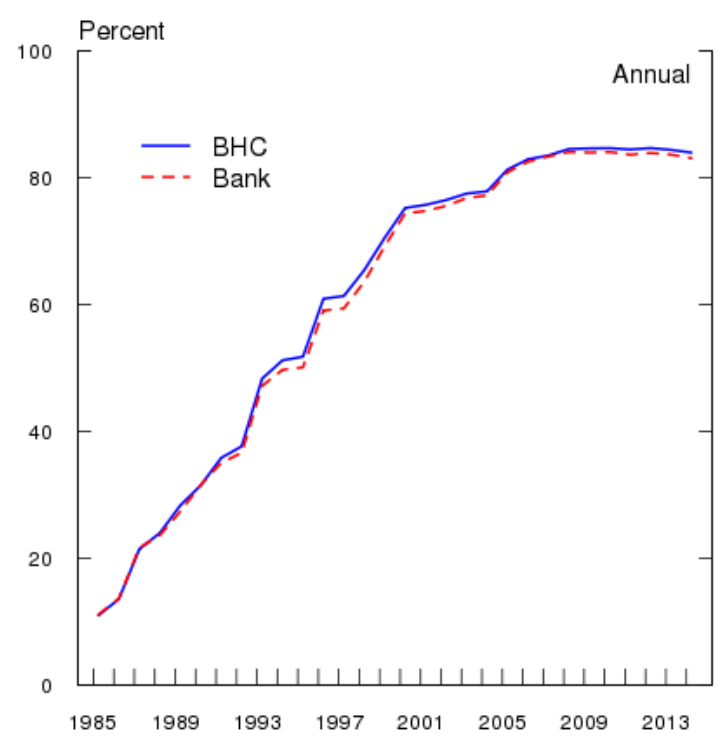

Figure shows share of $\mathrm{CBOs}$ and $\mathrm{RBOs}$ that operate a branch in a county where an $\mathrm{LBO}$ also operates a branch. Source: FFIEC Call Reports and FDIC's Summary of Deposits. 
Figure 5: CRE shares at CBOs and RBOs

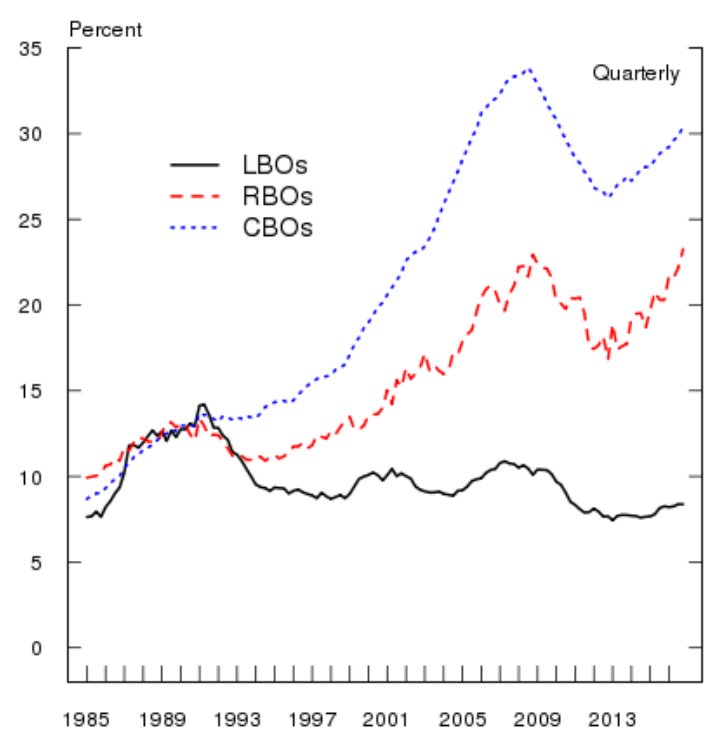

Figure shows share of CRE to total assets at CBOs and RBOs. Source: FFIEC Call Reports and FDIC's Summary of Deposits. 
Figure 6: CBO and RBO Loan Shares After LBO Market Entry

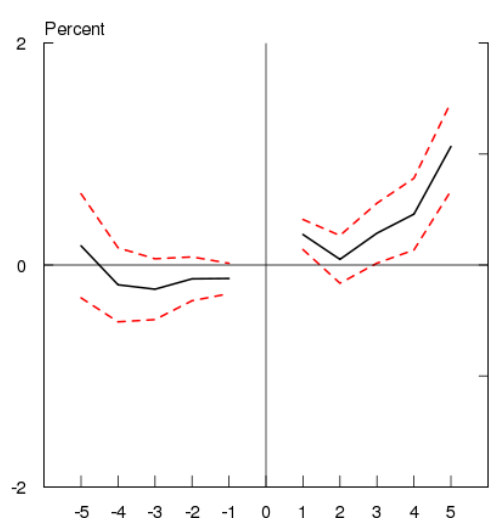

(a) $\mathrm{CRE}$

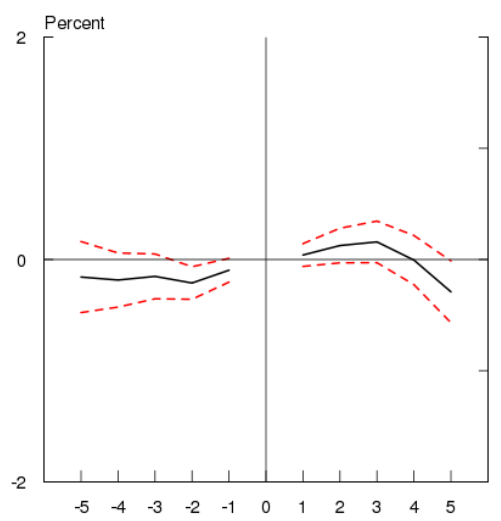

(c) $\mathrm{CI}$

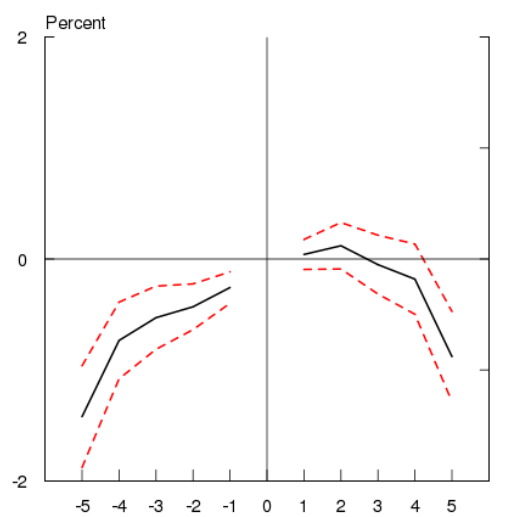

(b) RRE

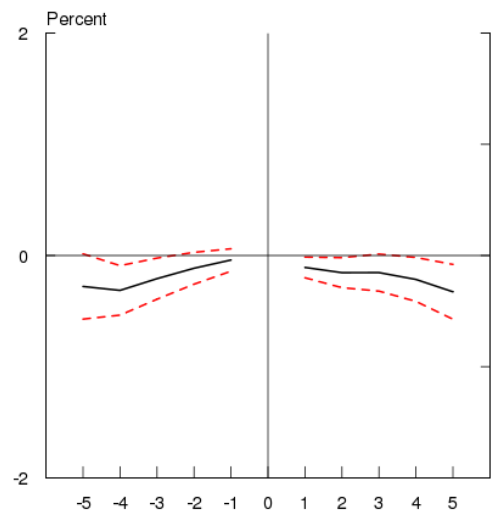

(d) Consumer

Figure shows coefficient estimates from leads and lags after LBO market entry for CBOs and RBOs. Source: FFIEC Call Reports and FDIC's Summary of Deposits. 
Figure 7: CRE Shares in Balanced Panel

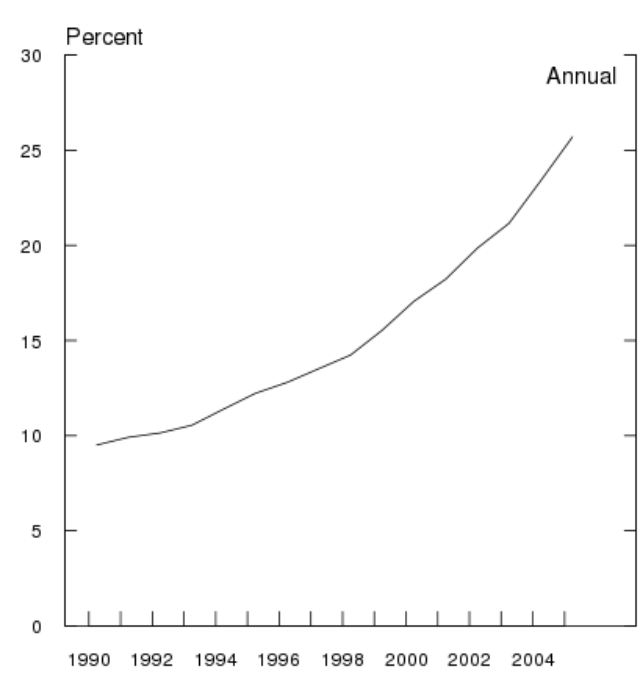




\section{Tables}

Table 1: Variable Descriptive Statistics

\begin{tabular}{lccc}
\hline \hline & Median & Mean & Std. Dev \\
\hline Dependent Share Variables & & & \\
CRE share & 10.61 & 14.09 & 12.11 \\
RRE share & 20.34 & 21.32 & 10.47 \\
CEI share & 8.17 & 9.67 & 6.82 \\
Cons share & 6.84 & 8.29 & 6.30 \\
LBO Competition Measures & & & \\
Log (LBO Deposits) & 10.32 & 7.24 & 6.11 \\
Log (LBO HHI Deposits) & 4.25 & 3.36 & 2.99 \\
Log (LBO HHI Branches) & 4.25 & 3.23 & 2.79 \\
Bank Controls & & & \\
NIM & 4.38 & 4.45 & 0.99 \\
Chargeoff Rate & 0.05 & 0.26 & 1.17 \\
Delin. Rate & 2.13 & 2.80 & 2.64 \\
Tier 1 Lev Ratio & 9.03 & 9.72 & 23.50 \\
County Macro Controls & & & \\
Log (Population) & 10.63 & 10.88 & 1.28 \\
Log (Per Capita Income) & 10.01 & 10.02 & 0.27 \\
Log (Bldg Permits) & 5.15 & 5.16 & 1.97 \\
Loan Growth Rates & & & \\
DLog (CRE) & 13.03 & 22.37 & 48.74 \\
DLog (RRE) & 7.79 & 12.08 & 24.32 \\
DLog (CI) & 7.59 & 12.97 & 35.67 \\
DLog (Cons) & 2.55 & 5.85 & 25.78 \\
\hline \hline
\end{tabular}

Note: The sample includes only banks held by BHCs with real assets (in 2009 dollars) less than $\$ 50$ billion from 1991 to 2005 . Local area conditions are county level measures weighted by branch shares as determined by the Summary of Deposits data. 
Table 2: Effect of LBO Activity on Community and Regional Bank CRE Shares

\begin{tabular}{|c|c|c|c|}
\hline & $\begin{array}{c}(1) \\
\log (\text { Deposit HHI })\end{array}$ & $\begin{array}{c}(2) \\
\log (\text { Branch HHI })\end{array}$ & $\begin{array}{c}(3) \\
\log (\text { LBO Deposits }\end{array}$ \\
\hline$L B O$ Activity $_{i, t-1}$ & $\begin{array}{c}0.0904^{* * *} \\
(4.76)\end{array}$ & $\begin{array}{c}0.0867^{* * *} \\
(4.40)\end{array}$ & $\begin{array}{c}0.0470^{* * *} \\
(4.90)\end{array}$ \\
\hline \multicolumn{4}{|l|}{ Bank-Specific Conditions } \\
\hline$\Delta \log (C R E)_{i, t-1}$ & $\begin{array}{c}0.00806^{* * *} \\
\quad(17.22)\end{array}$ & $\begin{array}{c}0.00806^{* * *} \\
(17.23)\end{array}$ & $\begin{array}{l}0.00805^{* * *} \\
(17.20)\end{array}$ \\
\hline$N I M_{i, t-1}$ & $\begin{array}{c}0.281^{* * *} \\
(3.76)\end{array}$ & $\begin{array}{c}0.281^{* * *} \\
(3.76)\end{array}$ & $\begin{array}{c}0.282^{* * *} \\
(3.77)\end{array}$ \\
\hline Chargeoff Rate $_{i, t-1}$ & $\begin{array}{c}-0.0745^{* * *} \\
(-3.47)\end{array}$ & $\begin{array}{c}-0.0747^{* * *} \\
(-3.48)\end{array}$ & $\begin{array}{c}-0.0744^{* * *} \\
(-3.46)\end{array}$ \\
\hline Delin. Rate ${ }_{i, t-1}$ & $\begin{array}{c}-0.0881^{* * *} \\
(-5.74)\end{array}$ & $\begin{array}{c}-0.0881^{* * *} \\
(-5.73)\end{array}$ & $\begin{array}{c}-0.0886^{* * *} \\
(-5.77)\end{array}$ \\
\hline Tier 1 Lev Ratio $_{i, t-1}$ & $\begin{array}{c}-0.00116 \\
(-1.01)\end{array}$ & $\begin{array}{c}-0.00118 \\
(-1.02)\end{array}$ & $\begin{array}{c}-0.00117 \\
(-1.01)\end{array}$ \\
\hline \multicolumn{4}{|l|}{ Local Market Conditions } \\
\hline $\log (\text { Population })_{i, t-1}$ & $\begin{array}{c}2.083^{* * *} \\
(8.25)\end{array}$ & $\begin{array}{c}2.104^{* * *} \\
(8.35)\end{array}$ & $\begin{array}{c}2.055^{* * *} \\
(8.09)\end{array}$ \\
\hline Log $(\text { Per Capita Income })_{i, t-1}$ & $\begin{array}{c}4.081^{* * *} \\
(4.22)\end{array}$ & $\begin{array}{c}4.062^{* * *} \\
(4.20)\end{array}$ & $\begin{array}{c}4.061^{* * *} \\
(4.20)\end{array}$ \\
\hline $\log (R R E \text { Permits })_{i, t-1}$ & $\begin{array}{c}0.290^{* * *} \\
(4.21)\end{array}$ & $\begin{array}{c}0.289^{* * *} \\
(4.21)\end{array}$ & $\begin{array}{c}0.289^{* * *} \\
(4.20)\end{array}$ \\
\hline Constant & $\begin{array}{c}-54.63^{* * *} \\
(-5.87)\end{array}$ & $\begin{array}{c}-54.66^{* * *} \\
(-5.87)\end{array}$ & $\begin{array}{c}-54.13^{* * *} \\
(-5.81)\end{array}$ \\
\hline Observations & 66,893 & 66,893 & 66,893 \\
\hline Adjusted $\mathrm{R}^{2}$ & 0.40 & 0.40 & 0.40 \\
\hline
\end{tabular}

Notes: Dependent variable is CRE loans as a share of total assets. The sample includes only banks held by BHCs with real assets (in 2009 dollars) less than $\$ 50$ billion from 1991 to 2005 . All regressions include year and bank fixed effects. Local area conditions are county level measures weighted by branch shares as determined by the Summary of Deposits data. Standard errors clustered at the bank level.

$t$ statistic in parentheses. ${ }^{*} p<0.10,{ }^{* *} p<0.05,{ }^{* * *} p<0.01$ 
Table 3: LBO Market Activity Effect on Non-CRE Loan Shares

\begin{tabular}{|c|c|c|c|c|c|}
\hline & $\begin{array}{c}(1) \\
\mathrm{RRE}\end{array}$ & $\begin{array}{c}(2) \\
\text { C\&I }\end{array}$ & $\begin{array}{c}(3) \\
\text { All Consumer }\end{array}$ & $\begin{array}{c}(4) \\
\text { Non-Credit Card }\end{array}$ & $\begin{array}{c}(5) \\
\text { Credit Cards }\end{array}$ \\
\hline $\log \left(L B O\right.$ Deposits $_{i, t-1}$ & $\begin{array}{c}-0.0279^{* * *} \\
(-2.75)\end{array}$ & $\begin{array}{c}-0.00251 \\
(-0.38)\end{array}$ & $\begin{array}{c}-0.0275^{* * *} \\
(-4.33)\end{array}$ & $\begin{array}{c}-0.0266^{* * *} \\
(-4.37)\end{array}$ & $\begin{array}{c}0.00272 \\
(0.57)\end{array}$ \\
\hline $\log (\text { LBO HHI Deposits) })_{i, t-1}$ & $\begin{array}{c}-0.0477^{* *} \\
(-2.40)\end{array}$ & $\begin{array}{c}0.00100 \\
(0.07)\end{array}$ & $\begin{array}{c}-0.0538^{* * *} \\
(-4.38)\end{array}$ & $\begin{array}{c}-0.0503^{* * *} \\
(-4.25)\end{array}$ & $\begin{array}{c}0.00114 \\
(0.13)\end{array}$ \\
\hline Log $(\text { LBO HHI Branches })_{i, t-1}$ & $\begin{array}{c}-0.0569^{* * *} \\
(-2.73)\end{array}$ & $\begin{array}{c}-0.00459 \\
(-0.33)\end{array}$ & $\begin{array}{c}-0.0547^{* * *} \\
(-4.23)\end{array}$ & $\begin{array}{c}-0.0524^{* * *} \\
(-4.21)\end{array}$ & $\begin{array}{c}0.00557 \\
(0.59)\end{array}$ \\
\hline
\end{tabular}

Notes: Table shows the coefficient estimates on LBO activity measures corresponding to the specfication given by equation 4 . The dependent variable is loans as a share of total assets. LBO activity is measured using each of three market concentration measures based on deposit and branch shares of LBO banks. The sample includes only banks held by BHCs with real assets (in 2009 dollars) less than $\$ 50$ billion from 1991 to 2005. All regressions include year and bank fixed effects. Standard errors clustered at the bank level. $t$ statistic in parentheses. ${ }^{*} p<0.10,{ }^{* *} p<0.05,{ }^{* * *} p<0.01$ 
Table 4: Instrumented LBO Activity Effect on Local Bank CRE Shares

\begin{tabular}{|c|c|c|c|}
\hline & $\begin{array}{c}(1) \\
\log (\text { LBO Deposits })\end{array}$ & $\begin{array}{c}(2) \\
\log (\text { Deposit HHI })\end{array}$ & $\begin{array}{c}(3) \\
\log (\text { Branch HHI })\end{array}$ \\
\hline$L B O$ Activity $_{i, t-1}$ & $\begin{array}{c}0.110^{* * *} \\
(5.87)\end{array}$ & $\begin{array}{c}0.218^{* * *} \\
(5.86)\end{array}$ & $\begin{array}{c}0.221^{* * *} \\
(5.85)\end{array}$ \\
\hline \multicolumn{4}{|l|}{ Bank-Specific Conditions } \\
\hline$\Delta \log (C R E)_{i, t-1}$ & $\begin{array}{l}0.00807^{* * *} \\
\quad(17.21)\end{array}$ & $\begin{array}{l}0.00808^{* * *} \\
\quad(17.26)\end{array}$ & $\begin{array}{c}0.00809^{* * *} \\
\quad(17.28)\end{array}$ \\
\hline$N_{I} M_{i, t-1}$ & $\begin{array}{c}0.282^{* * *} \\
(3.78)\end{array}$ & $\begin{array}{c}0.281^{* * *} \\
(3.77)\end{array}$ & $\begin{array}{c}0.279^{* * *} \\
(3.75)\end{array}$ \\
\hline Chargeoff Rate $_{i, t-1}$ & $\begin{array}{c}-0.0736^{* * *} \\
(-3.43)\end{array}$ & $\begin{array}{c}-0.0739^{* * *} \\
(-3.44)\end{array}$ & $\begin{array}{c}-0.0742^{* * *} \\
(-3.46)\end{array}$ \\
\hline Delin. Rate $_{i, t-1}$ & $\begin{array}{c}-0.0892^{* * *} \\
(-5.81)\end{array}$ & $\begin{array}{c}-0.0881^{* * *} \\
(-5.74)\end{array}$ & $\begin{array}{c}-0.0880^{* * *} \\
(-5.74)\end{array}$ \\
\hline Tier 1 Lev Ratio Rit -1 & $\begin{array}{c}-0.00109 \\
(-0.97)\end{array}$ & $\begin{array}{c}-0.00108 \\
(-0.96)\end{array}$ & $\begin{array}{c}-0.00112 \\
(-0.99)\end{array}$ \\
\hline \multicolumn{4}{|l|}{ Local Market Conditions } \\
\hline $\log (\text { Population })_{i, t-1}$ & $\begin{array}{c}1.871^{* * *} \\
(7.33)\end{array}$ & $\begin{array}{c}1.933^{* * *} \\
(7.63)\end{array}$ & $\begin{array}{c}1.971^{* * *} \\
(7.82)\end{array}$ \\
\hline $\log (\text { Per Capita Income })_{i, t-1}$ & $\begin{array}{c}4.110^{* * *} \\
(4.26)\end{array}$ & $\begin{array}{c}4.161^{* * *} \\
(4.30)\end{array}$ & $\begin{array}{c}4.121^{* * *} \\
(4.26)\end{array}$ \\
\hline $\log (R R E \text { Permits })_{i, t-1}$ & $\begin{array}{c}0.282^{* * *} \\
(4.11)\end{array}$ & $\begin{array}{c}0.284^{* * *} \\
(4.14)\end{array}$ & $\begin{array}{c}0.283^{* * *} \\
(4.12)\end{array}$ \\
\hline Observations & 66,565 & 66,565 & 66,565 \\
\hline Adjusted $\mathrm{R}^{2}$ & 0.34 & 0.34 & 0.34 \\
\hline
\end{tabular}

Notes: Dependent variable is CRE loans as a share of total assets. The LBO activity measure is instrumented with the minimum distance between a CBO's main office and the closest LBO branch. The sample includes only banks held by BHCs with real assets (in 2009 dollars) less than $\$ 50$ billion from 1991 to 2005 . All regressions include year and bank fixed effects. Local area conditions are county level measures weighted by branch shares as determined by the Summary of Deposits data. Standard errors clustered at the bank level.

$t$ statistic in parentheses. ${ }^{*} p<0.10,{ }^{* *} p<0.05,{ }^{* * *} p<0.01$ 
Table 5: Instrumented LBO Activity Effect on Local Bank Non-CRE Shares

\begin{tabular}{lccccc}
\hline \hline & $(1)$ & $(2)$ & $(3)$ & $(4)$ & $(5)$ \\
& RRE & C\&I & All Consumer & Non-Credit Card & Credit Cards \\
\hline Log (LBO Deposits $)_{i, t-1}$ & $-0.0737^{* * *}$ & -0.0131 & $-0.0395^{* * *}$ & $-0.0334^{* * *}$ & -0.00201 \\
& $(-3.84)$ & $(-0.96)$ & $(-3.00)$ & $(-2.79)$ & $(-0.12)$ \\
Log (LBO HHI Deposits) $)_{i, t-1}$ & $-0.145^{* * *}$ & -0.0258 & $-0.0777^{* * *}$ & $-0.0659^{* * *}$ & -0.00400 \\
& $(-3.84)$ & $(-0.96)$ & $(-2.99)$ & $(-2.79)$ & $(-0.12)$ \\
$\log (\text { LBO HHI Branches })_{i, t-1}$ & $-0.148^{* * *}$ & -0.0263 & $-0.0791^{* * *}$ & $-0.0670^{* * *}$ & -0.00412 \\
& $(-3.84)$ & $(-0.96)$ & $(-3.00)$ & $(-2.79)$ & $(-0.12)$ \\
\hline \hline
\end{tabular}

Notes: Table shows the coefficient estimates on LBO activity measures corresponding the specfication given by equation 4 . The LBO activity measure is instrumented with the minimum distance between a CBO's main office and the closest LBO branch. The dependent variable is loans as a share of total assets. LBO activity is measured using each of three market concentration measures based on deposit and branch shares of LBO banks. The sample includes only banks held by BHCs with real assets (in 2009 dollars) less than $\$ 50$ billion from 1991 to 2005 . All regressions include year and bank fixed effects. Standard errors clustered at the bank level. $t$ statistic in parentheses. ${ }^{*} p<0.10,{ }^{* *} p<0.05,{ }^{* * *} p<0.01$ 